\section{Ida Conar}

Svenciliste u Zagrebu, Uciiteljski fakultet, Odsjek Cakovec

Andreja Brajša-Žganec

Institut drustvenih znanosti Ivo Pilar

\section{Povezanost poremećaja izgovora sa samopoimanjem djece predškolske i prvog razreda osnovnoškolske dobi}

\author{
The connection between articulation disorder \\ and self-concept of preschool children and \\ first graders of primary school
}

Stručni rad UDK: 616.89-008.434:159.923.2-053.4 https://doi.org/10.31299/log.8.2.2

\begin{abstract}
SAŽETAK
Cilj ovog istraživanja je ispitivanje povezanosti poremećaja izgovora glasova sa samopoimanjem. Uzorak je činilo 74 ispitanika u dobi od 6,5 do 7,5 godina, odnosno 29 ispitanika s poremećajem izgovora i 45 ispitanika bez poremećaja izgovora. Primijenjena je adaptirana verzija upitnika Susan Harter - Slikovne skale opaženih kompetencija i prihvaćenosti za djecu, čija pouzdanost je prethodno ispitana. Statističkom analizom uočeno je postojanje značajnih razlika u kognitivnom i društvenom samopoimanju među navedenim skupinama. Utvrđeno je kako ispitanici s dijagnozom poremećaja izgovora imaju niže kognitivno $(t=2,25, p<0,05)$ i društveno samopoimanje $(\mathrm{t}=2,91, \mathrm{p}<0,01)$ nego ispitanici bez poremećaja izgovora. Također, analizom rezultata specifičnih čestica upitnika, čiji je sadržaj usmjeren ispitivanju samopoimanja govora, utvrđena je statistički značajna razlika među navedenim skupinama - niže rezultate imali su ispitanici s dijagnozom poremećaja izgovora. Istraživanjem nije utvrđena statistički značajna razlika između skupina u samopoimanju tjelesnih sposobnosti. Utvrđeno je da postoji visoka pozitivna povezanost samopoimanja kognitivnih sposobnosti i društvene prihvaćenosti. Slaba pozitivna povezanost utvrđena je za subskalu tjelesnih sposobnosti sa subskalama kognitivnih sposobnosti i društvene prihvaćenosti. Također, utvrđena je blaga pozitivna povezanost među česticama o samoprocjeni govora i izgovora. Rezultati istraživanja pokazuju kako se djeca s poremećajem izgovora razlikuju od svojih vršnjaka koji nemaju navedeni poremećaj u procjenama samopoimanja kognitivnih sposobnosti i samopoimanja društvene prihvaćenosti, a nije utvrđena razlika u kontekstu procjena samopoimanja tjelesnih sposobnosti.
\end{abstract}

Ključne riječi: poremećaj izgovora samopoimanje - govor djeca

Keywords: articulation disorder self-concept speech children 


\section{UVOD}

Djetinjstvo je razdoblje dinamičnog i intenzivnog razvoja pojedinca na više razina: tjelesnoj, kognitivnoj, emocionalnoj i socijalnoj razini (Berk, 2007). Jedno od osnovnih obilježja djetinjstva svojevrsna je ovisnost pojedinca o svojoj okolini s kojom se nastoji povezati te, s druge strane, potreba za samostalnošću i kompetencijom djelovanja u toj okolini (White, 1959, Harter, 1978, 1985, 1992, prema Almeida, Valentini i Berleze, 2008). Između ranog djetinjstva i adolescencije, djeca sve više postaju svjesna svojih karakteristika, kritički se postavljaju prema okolini, ali i prema sebi kako bi sebe i okolinu bolje razumjeli (Berk, 2015). Jedna od važnih komponenti razvoja u tom razdoblju je i razvoj govora - ključan za uspješnu socijalizaciju pojedinca, njegovu komunikaciju s okolinom, akademski uspjeh i druge aspekte njegova uspješnog funkcioniranja (Jukić i Elez, 2013). S razvojem govora mogu se pojaviti govorni, glasovni i/ili jezični poremećaji, koji mogu biti privremeniili trajno ostati u govoru pojedinca (Šimić, 2015). Brojni događaji i situacije - pojava poteškoća $\mathrm{u}$ interakciji sdrugom djecom, autoritarno roditeljsko okruženje, napetosti u obitelji i slično - često utječu na razvoj djetetova jezika i govora. Oni mogu narušiti djetetovu osobnost i dovesti do brojnih teškoća te emocionalnih poremećaja (Moreno Manso i Mateos Garcia, 2005). S druge strane, pozitivna slika o sebi razvija se u okruženju koje djetetu daje osjećaj razumijevanja, prihvaćenosti i podrške (Brajša-Žganec, Raboteg-Šarić i Franc, 2000). Ako se ne uklone na adekvatan način, govorne se poteškoće najčešće produbljuju i integriraju u djetetov govor. Govorni poremećaj javlja se najčešće usporedno s razvojem govora, pa se okolina, a i sam govornik, često postupno na to priviknu i s vremenomga više i ne primjećuju (LebedinaManzoni, Novak i Jeđud, 2006).

Prema Susan Harter, autorici upitnika primijenjenog u predstavljenom istraživanju, samopoimanje je višedimenzionalni konstrukt u kojem pojedinac sebe procjenjuje $u$ više odvojenih kategorija kroz koje se percepcija kompetencija može razlikovati, ali on ujedno stvara i opću percepciju sebe kao individue (Harter, 1990, prema Brajša-ŽZganec i sur., 2000). Također, samopoimanje nije nepromjenjiv konstrukt, već se ono mijenja pod utjecajem bioloških i sociopsiholoških pretpostavki. Harter polazi od pretpostavke da djeca različito percipiraju različite domene svog djelovanja. Djeca u dobi od četiri do sedam godina dobro razlikuju svoja školska postignuća, socijalne odnose s vršnjacima, fizičke sposobnosti i odnos s majkom, zbog čega ona, u kontekstu upitnika Slikovne skale opaženih kompetencija i prihvaćenosti za djecu, formira četiri posebne subskale u četiri različite skupine pitanja koja se odnose na navedene domene (Lacković-Grgin, 1994). Isto tako, Harter tvrdi kako mlađa djeca nemaju jasan osjećaj globalnog samopoimanja. Zato upitnik primijenjen u ovom istraživanju obuhvaća pitanja o pojedinačnim komponentama samopoimanja, ali ne i skupinu pitanja o općenitom samopoimanju, kao što je to slučaj kod upitnika za djecu starije dobi (Vasta i sur., 1998).

Uočivši važnost poremećaja izgovora u životu pojedinca, José Armando Rivera Tinoco je 2012. proveo istraživanje o povezanosti samopoštovanja i poremećaja izgovora kod djece drugog i trećeg razreda redovnog školovanja u Republici Ekvador. Prema rezultatima navedenog istraživanja, poremećaj izgovora je povezan sa samopoimanjem i njegovim razvojem kod djece osnovnoškolske dobi. Međutim, istraživanje (Rivera Tinoco, 2012) se više bavilo pitanjem stajališta odraslih "važnijih drugih" o povezanosti poremećaja izgovora sa samopoštovanjem djeteta, a samopoimanje je procjenjivano globalno, bez diferencijacije posebnih domena istog. Navedeno istraživanje provedeno je na populaciji španjolske djece, a razvoj samopoimanja ovisi i o kulturološkoj sredini u kojoj dijete raste, vrijednostima i stavovima koje određeno društvo afirmira. Prema tome, rezultati dobiveni u navedenom istraživanju ne mogu se generalizirati, dobiveni se zaključci ne mogu preslikati na populaciju djece iz Hrvatske (Lacković-Grgin, 1994; Jelić, 2009). Druga istraživanja o povezanosti poremećaja izgovora i samopoimanja kod djece predškolske i osnovnoškolske dobi, nisu poznata.

Cilj ovog istraživanja jeispitati postoje li značajne razlike u pojedinim aspektima samopoimanja između djece predškolske i prvog razreda osnovnoškolske dobi, kojima je dijagnosticiran specifičan poremećaj izgovora i djece istog uzrasta bez navedene dijagnoze.

Prema cilju, definirani su i sljedeći problem istraživanja:

1) Utvrditi postoji li značajna razlika u samopoimanju kognitivnih sposobnosti, tjelesnih sposobnosti i društvene prihvaćenosti između djece predškolske i prvog razreda osnovnoškolske dobi koja imaju dijagnosticiran specifičan poremećaj izgovora i djece istog uzrasta koja nemaju poremećaj izgovora.

2) Utvrditi postoji li značajna razlika u samopoimanju između djece predškolske i prvog razreda osnovnoškolske dobi s poremećajem izgovora i djece navedene dobi bez poremećaja izgovora, s obzirom na specifična pitanja usmjerena i povezana s izgovorom.

3) Utvrditi postoji li povezanost među subskalama samopoimanja kognitivnih sposobnosti, tjelesnih sposobnosti i društvene prihvaćenosti.

4) Utvrditi postoji li povezanost među specifičnim pitanjima koja se odnose na utvrđivanje samopoimanja govora i izgovora.

\section{METODE}

\section{Ispitanici}

U istraživanju su u statističku obradu uzeti odgovori 74 ispitanika u dobi od 6,5 do 7,5 godina. Prije istraživanja, ispitanici su morali dobiti pismeni pristanak roditelja jer su ispitanici maloljetne osobe. Uzorak eksperimentalne skupine činilo je 29 ispitanika kojem je prethodno dijagnosticiran poremećaj izgovora (F 80.0). Uzorak kontrolne skupine činilo je 45 ispitanika navedene dobne skupine kod kojih nije prisutan poremećaj izgovora.

\section{Postupak}

Podaci su prikupljani od ožujka do rujna 2016. godine na Logopedskom odjelu Opće bolnice Varaždin, gdje su upitnik ispunjavali ispitanici koji čine eksperimentalnu skupi- 
nu, te u III. osnovnoj školi Varaždin i VI. osnovnoj školi Varaždin, čiji su ispitanici činili uzorak kontrolne skupine. Prije provođenja istraživanja, suglasnost za to dali su roditelji djece, stručne službe navedenih škola i Etičko povjerenstvo Opće bolnice Varaždin. Ispitanici su dobili opću uputu o ispunjavanju upitnika, koji im je čitan, s obzirom na pretpostavku nerazvijenosti sposobnosti čitanja sudionika, a koja je u skladu s njihovom dobi. Ispitanici su upitnike rješavali pod šifrom, time je zajamčena anonimnost. Sudjelovanje je bilo u skladu s načelima Etičkog kodeksa istraživanja s djecom (Napredak, 2003).

\section{Mjerni instrument}

Za potrebe ovog istraživanja primijenjen je sociodemografski upitnik, koji su ispunjavali roditelji ili skrbnici ispitanika, a željelo se utvrditi postoje li značajna sociodemografska odstupanja među ispitanicima pojedinih skupina. Analizom sociodemografskih podataka, dobiveni su sljedeći rezultati: od ukupnog broja ispitanika uzetih u statističku obradu, skupinu s dijagnozom poremećaja izgovora činilo je 62,07 \% dječaka i 37,93 \% djevojčica, a skupinu bez dijagnoze je činilo 51,11 \% dječaka i 48,89 \% djevojčica te je hi-kvadrat testom utvrđeno kako nema statistički značajne razlike među navedenim skupinama prema spolu $(\chi 2=0,86, \mathrm{df}=1, \mathrm{p}=$ n.s.). Nadalje, prosječan broj ćlanova kućanstva ispitanika s poremećajem izgovora je 5 , a u skupini ispitanika bez dijagnoze poremećaja izgovora prosječan broj članova je $4(\chi 2=3,5, \mathrm{df}=2, \mathrm{p}=$ n.s. $)$, dok je prosječan broj djece u kućanstvima u obje skupine 2 $(\chi 2=0,39, \mathrm{df}=2, \mathrm{p}=$ n.s.). Hi-kvadrat testom nije utvrđena statistički značajna razlika bračnog statusa roditelja ispitanika među skupinama $(\chi 2=0,12, \quad \mathrm{df}=1, \quad \mathrm{p}=$ n.s. $)$. Statistički značajna razlika uočena je u obrazovanju roditelja $(\chi 2=7,06$, $\mathrm{df}=2, \quad \mathrm{p}<0,05)$, pritom roditelji djece $\mathrm{s}$ poremećajem izgovora imaju statistički značajno niže obrazovanje u odnosu na roditelje ispitanika bez poremećaja izgovora. U obje se skupine većina roditelja izjasnila kao oni $u$ stalnom radnom odnosu (roditelji ispitanika s poremećajem izgovora $79,31 \%$, a roditelji ispitanika bez poremećaja izgovora 88,8 $\%$ te je hi-kvadrat testom utvrđeno kako nema statistički značajne razlike među ispitanicima s obzirom na radni status roditelja ispitanika $(\chi 2=2,47, \mathrm{df}=1, \mathrm{p}=$ n.s. $)$. Za pitanja procjena vlastitih prihoda izračunat je t-test, čime nije utvrđena statistički značajna razlika među ispitanicima $(\mathrm{t}=0,047, \quad \mathrm{df}=72, \quad \mathrm{p}=$ n.s. $) . \quad$ Kako značajnije razlike sociodemografskih podataka nisu utvrđene, u statističku obradu su uzeti svi ispitanici koji su zadovoljili kriterije istraživanja.

Za procjenu samopoimanja djece primijenjena je adaptirana verzija upitnika autorice Susan Harter, izvornog naziva The Pictorial Scale of Perceived Competence and Acceptance for Young Children, prevedenog kao Slikovne skale opaženih kompetencija i prihvaćenosti za djecu, namijenjenog djeci u dobi od četiri do sedam godina (Harter i Pike, 1981). Primijenjene su dvije inačice navedenog upitnika: za dječake i za djevojčice, ilustracije i tekstualni kontekst pitanja su prilagođeni rodnim karakteristikama ispitanika, a slijed i oblik pitanja u oba upitnika bili su isti. Svaka čestica je oblikovana tako da prikazuje dvije suprotne ilustracije, čiji je sadržaj opisan ispod iste (npr. uz ilustracije su pridružene sljedeće tvrdnje: “Ovaj dječak nije dobar u matematici." i "Ovaj dječak je dobar u matematici."), nakon toga slijedi samoprocjena ispitanika označavanjem onog odgovora koji je ispitaniku najbliži (npr. "Ja u matematici: Nisam dobar; Rijetko sam dobar; Često sam dobar; Uvijek sam dobar"). Rezultat se boduje na skali od četiri stupnja gdje "1" znači samoprocjenu najmanje, a "4" samoprocjenu najveće vrijednosti. Ukupan rezultat je prosjek rezultata svih čestica određene subskale, što znači da može iznositi najmanje 1, a najviše 4 (Harter i Pike, 1983). Instrument je oblikovan tako da ispitanici procjenjuju sebe u četiri odvojena područja samopoimanja koja se odnose na kognitivne i tjelesne sposobnosti te socijalnu i majčinsku prihvaćenost. Isti se sastoji od 24 čestice koje čine navedene četiri subskale, pritomje originalni set od šest pitanja zadržan za subskale Kognitivne sposobnosti i Tjelesne sposobnosti (Harter i Pike, 1983), dok je 24. čestica originalnog upitnika za potrebe istraživanja preoblikovana i iz izvornog "Razgovara li tvoja majka s tobom: Uvijek; Često; Ponekad; Rijetko" preoblikovana u "Ja s drugima razgovaram: Uvijek; Često; Ponekad; Rijetko", te je kao takva svrstana u set pitanja subskale Društvena prihvaćenost. Ujedno su rezultati navedene čestice, uz rezultate 17 . čestice "Ja u izgovaranju riječi: Nisam dobar/dobra; Rijetko sam dobar/dobra; Često sam dobar/dobra; Uvijek sam dobar/dobra", analizirani i posebno kao one čestice kojima se ispituje samopoimanje govora i govornih sposobnosti, a što je bio prijedlog Susan Harter. Prema navedenom, subskalu Majčinska prihvaćenost činilo je pet, dok je subskala Društvena prihvaćenost sadržavala sedam čestica. Za potrebe ovog istraživanja, instrument je preveden na hrvatski jezik te ponovno na engleski jezik za kontrolu točnosti prijevoda, a kao pokazatelj pouzdanosti pojedine subskale upitnika izračunati su Cronbach $\alpha$ koeficijenti. Dobiveni $\alpha$ koeficijenti slični su koeficijentima koje su dobili Harter i Pike (1984) za pripadajuće subskale. Pritom je utvrđena vrlo loša pouzdanost subskale Majčinska prihvaćenost te zato ona nije uzimana u daljoj obradi podataka $\mathrm{i}$ analizi rezultata. Zbog niske pouzdanosti dobivene za subskalu Tjelesne sposobnosti, iz te subskale izuzeta je Čestica 23. ("Ja sam u preskakivanju užeta: Uvijek dobar/dobra; Često dobar/dobra; Rijetko dobar/dobra; Nisam dobar/dobra"), te je navedena subskala u dalju statističku obradu uzeta s pet preostalih čestica $(\alpha=0,53)$. Zadovoljavajuća pouzdanost utvrđena je za subskalu Kognitivne sposobnosti $(\alpha=0,65)$ i Društvena prihvaćenost $(\alpha=0,74)$, time su iste uzete $u$ dalju statističku obradu, analizu i donošenje zaključaka.

\section{REZULTATI I RASPRAVA}

$\mathrm{Na}$ osnovi prikupljenih podataka, izračunati su deskriptivni pokazatelji, kao i t-test za nezavisne uzorke za svaku subskalu pojedinačno i za odabrane čestice te korelacijska analiza subskala i odabranih čestica. Prema prethodnim analizama, statističkom obradom obuhvaćeni su rezultati subskala: Kognitivne sposobnosti, Društvena prihvaćenost i Tjelesne sposobnosti te rezultati Čestice 17. i Čestice 24.

Aritmetičke sredine rezultata prikazane su grafikonom 1. Vidljivo je kako su rezultati svih subskala i pojedinačnih čestica relativno visokih vrijednosti, što je u skladu $s$ teorijskim postavkama: budući da djeca predškolske dobi 
teško razlikuju stvarne vlastite sposobnosti od onih koje bi isti željeli imati, oni procjenjuju svoje sposobnosti vrlo visokima (Berk, 2015). Takvo samopoimanje je tijekom srednjeg i kasnog djetinjstva relativno stabilno (Vasta i sur., 1998).

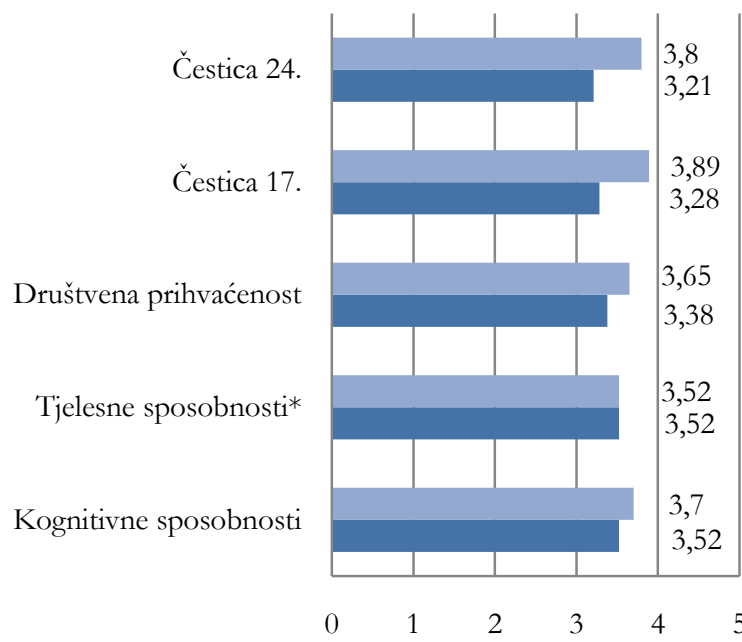

Ispitanici bez poremećaja izgovora

- Ispitanici s poremećajem izgovora

Grafikon 1. Aritmetička sredina rezultata za ispitanike s poremećajem izgovora i bez poremećaja izgovora (* podaci temeljeni na izračunima seta od pet čestica)

Prosječna vrijednost rezultata subskale Kognitivne sposobnosti veća je kod skupine ispitanika bez poremećaja izgovora $\mathrm{u}$ odnosu na prosječnu vrijednost rezultata za skupinu ispitanika s poremećajem izgovora. Također, uočava se veća prosječna vrijednost rezultata subskale Društvena prihvaćenost u korist ispitanika skupine bez poremećaja izgovora, za razliku prosječne vrijednosti rezultata ispitanika s istoimenom dijagnozom. Veću razliku prosječnih vrijednosti rezultata od navedenih između skupina, moguće je uočiti kod Čestice 17. Prosječne vrijednosti rezultata za subskalu Tjelesne sposobnosti za skupinu bez poremećaja izgovora čine najmanju razliku prosječnih vrijednosti rezultata među skupinama u odnosu na preostale rezultate.

U tablici 3. prikazane su vrijednosti t-testova ispitivanih subskala i čestica. Iz te je tablice vidljivo kako među skupinama ispitanika $\mathrm{s}$ poremećajem izgovora i bez poremećaja izgovora postoji statistički značajna razlika samopoimanja kognitivnih sposobnosti $(t=2,25, d f=72$, $\mathrm{p}<0,05)$ i društvene prihvaćenosti $(\mathrm{t}=2,91, \mathrm{df}=72, \mathrm{p}<0,01)$, pritom su ispitanici skupine bez poremećaja izgovora ostvarili statistički značajno više rezultate. Ako se promatraju rezultati posebnih čestica, također se može uočiti statistički značajna razlika među navedenim skupinama u vrijednostima u korist ispitanika bez dijagnoze poremećaja izgovora. Najveća t-vrijednost $\mathrm{u}$ t-testu ostvarena je kod Čestice 17. ( $t=4,63, \mathrm{df}=72, \mathrm{p}<0,01)$, čiji se sadržaj direktno odnosi na procjenu uspješnosti govora kod ispitanika. Za Česticu 24., koja se odnosi na primjenu govora, također je uočena statistički značajna razlika među skupinama $(\mathrm{t}=3,34, \mathrm{df}=72, \mathrm{p}<0,01)$. Vrijednosti $\mathrm{t}$-testa subskale Tjelesne sposobnosti $(\mathrm{t}=0,08, \mathrm{df}=72, \mathrm{p}=\mathrm{n} . \mathrm{s}$. pokazuju da ne postoji statistički značajna razlika u samopoimanju među ispitanim skupinama za navedenu subskalu.

Tablica 3. Vrijednosti t-testa za subskale i čestice (*podaci temeljeni na izračunima seta od pet čestica)

\begin{tabular}{|l|c|c|c|}
\hline & $\mathbf{t}$ & $\mathbf{d f}$ & $\mathbf{p}$ \\
\hline Kognitivne sposobnosti & 2,25 & 72 & $<0,05$ \\
\hline Tjelesne sposobnosti* & 0,08 & 72 & n. s. \\
\hline Društvena prihvaćenost & 2,91 & 72 & $<0,01$ \\
\hline Čestica 17. & 4,63 & 72 & $<0,01$ \\
\hline Čestica 24. & 3,34 & 72 & $<0,01$ \\
\hline
\end{tabular}

Za ispitivanje moguće povezanosti subskala te odabranih čestica, provedene su korelacijske analize, na osnovi kojih su dobivene korelacijske matrice $\mathrm{s}$ vrijednostima Pearsonovog koeficijenta za povezanost subskala, odnosno čestica.

Pokazalo se kako su subskale Kognitivne sposobnosti i Društvena prihvaćenost visoko pozitivno povezane ( $\mathrm{r}=0,71$, $\mathrm{p}<0,01)$. Iz navedenog se može zaključiti - kako je samopoimanje pojedinca u jednom od područja (kognitivnom (školskom) ili društvenom (vršnjačkom)) povezano sa samopoimanjem drugog navedenog područja. Uočena je slaba pozitivna povezanost subskale Tjelesne sposobnosti sa subskalom Kognitivne sposobnosti ( $\mathrm{r}=0,29$, $\mathrm{p}<0,01)$ i sa subskalom Društvena prihvaćenost $(\mathrm{r}=0,23$, $\mathrm{p}<0,05)$, što znači kako su kognitivno i društveno samopoimanje puno manje povezani s tjelesnim samopoimanjem u odnosu na korelaciju kognitivnih sposobnosti i društvene prihvaćenosti i obratno.

Korelacijom Čestice 17. i Čestice 24., uočena je blaga pozitivna povezanost $(\mathrm{r}=0,35, \mathrm{p}<0,01)$ - to potvrđuje kako se percepcija izgovora povezuje s potrebom i praksom razgovora i komunikacije, što je također povezano sa socijalizacijom te prosocijalnim i komunikacijskim vještinama.

Uočeno sniženo samopoimanje djece s poremećajem izgovora u kontekstu kognitivnih sposobnosti u odnosu na vršnjake bez poremećaja izgovora, ukazuje na tvrdnju kako djeca svoje predškolske i školske aktivnosti i uspjehe uspoređuju s rezultatima koje su u istom području postigli njihovi vršnjaci, te se - ovisno o samopercepciji uspješnosti u odnosu na njih - smatraju više ili manje uspješnima (Šola, 2017). To ponajprije potvrđuju rezultati koji se odnose na čestice, čiji se sadržaj direktno odnosi na procjenu uspješnosti govora kod ispitanika, a gdje je uočena najveća razlika među ispitanicima. Pozitivna povezanost među subskalama društvene prihvaćenosti i kognitivnih sposobnosti potvrđuje tvrdnju kako govor "[...] nije samo sredstvo komunikacije, već i sredstvo razmišljanja i društvene interakcije (Greenspan, 2004, str. 26)". Izgovor, kao dio govora, utječe na ostvarenje govora i tako sudjeluje u oblikovanju razmišljanja, društvenog djelovanja i 
interakcije pojedinca (Šego, 2009). To potvrđuje i istraživanje koje je proveo Rivera Tinoco (2012), gdje ispitani učitelji smatraju da djeca s dijagnozom poremećaja izgovora govore jako malo ili ništa u nastavi (navedenu tvrdnju zastupa $50 \%$ ispitanih učitelja) i da ne sudjeluju u grupnim aktivnostima (što smatra $16,6 \%$ ispitanih učitelja).

\section{ZAKLJUČAK}

Ovim istraživanjem ukazano je na potrebu za razumijevanjem i obraćanjem pozornosti na djecu s poremećajem izgovora u predškolskoj dobi i prvom razredu osnovnoškolske dobi. Uzimajući u obzir teoriju ekološkog pristupa, uža i šira okolina u kojoj se pojedinac nalazi posredno i neposredno oblikuju pojedinca te utječu na njegov razvoj u svim aspektima, pa tako $i$ na razvoj samopoimanja (Berk, 2015). Okolina, ponajprije djetetovi roditelji i uža obitelj, trebali bi pružati podršku i poticati pojedinca razvoju pozitivne slike o sebi, naglašavajući uspjehe i dostignuća pojedinca u svim segmentima u kojima se oni očituju, posebice u kontekstu društvenih te predškolskih i školskih aktivnosti. S obzirom na to da, prema rezultatima istraživanja, djeca $\mathrm{s}$ poremećajem izgovora imaju poteškoća u samopoimanju društvenog prihvaćanja i kognitivnih sposobnosti, odgajatelji, učitelji, roditelji, stručni suradnici i okolina trebali bi pomagati poticati djecu s poremećajem izgovora u razvoju socijalne interakcije s drugima. Time bi se proaktivno utjecalo na pozitivan razvoj samopoimanja u području društvenih sposobnosti. Također, odgajatelji i učitelji trebalibi djeci s dijagnozom poremećaja izgovora - kroz obrazovni sustav osigurati takve oblike rada, koji će kod djece poticati osjećaj kompetentnosti u obavljanju školskih ili predškolskih zadaća. Djeci s poremećajem izgovora šira društvena zajednica trebala bi omogućiti pravodobnu i stručnu logopedsku pomoć u uklanjanju ili smanjenju poremećaja izgovora (ako je isti moguće djelomično ili potpuno ukloniti), te omogućiti svim stručnim službama, ponajprije odgajateljima i učiteljima, stručnu edukaciju o poremećajima izgovora, načinu rada i pristupu djeci s poremećajem izgovora u odgojno-obrazovnom procesu. Tako bi se moglo utjecati na pozitivniji razvoj samopoimanja kod djece s poremećajem izgovora, osobito u području kognitivnih sposobnosti i društvene prihvaćenosti.

\section{LITERATURA}

1) Almeida, G., Valentini, N. C., \& Berleze, A. (2009). Perceptions of competence in a study with children and adolescents from elementary school. Movimento, 15, 1, 71-97. 2) Berk, L. E. (2007). Psihologija cjeloživotnog razuoja. Jastrebarsko: Naklada Slap.

3) Berk, L. E. (2015). Dječja raquojna psibologija. Jastrebarsko: Naklada Slap.

4) Brajša-Žganec, A., Ragboteg-Šarić, Z. i Franc, R. (2000). Dimenzije samopoimanja djece u odnosu na opaženu socijalnu podršku iz različitih izvora. Društvena istraživanja Zagreb, 6, 50, 897-912.
5) Etički kodeks istraživanja s djecom (2003). Napredak, 144, 4, 529-537.

6) Greenspan, S. L. (2004). Program emocionalnog poticanja govorno-jezičnog razvoja. Zagreb: Ostvarenje.

7) Harter, S., \& Pike R. G. (1981). The Pictorial Scale of Perceived Competence and Acceptance for Young Children. Denver: University of Denver.

8) Harter, S., \& Pike R. G. (1983). Procedural Manual to Accompany: The Pictorial Scale of Perceived Competence and Acceptance for Young Children. Denver: University of Denver.

9) Harter, S., \& Pike, R. (1984). The pictorial scale of perceived competence and social acceptance for young children. Child development, 55, 1969-1982. doi: dx.doi.org/10.2307/1129772

10) Jelić M. (2009). Što vidimo u ogledalu: pojam o sebi $i$ samopoštovanje. U: D. Čorkalo-Biruški (ur.). Primijenjena psihologija: dvadeset pitanja, dvadeset odgovora (str. 81-99). Zagreb: Školska knjiga.

11) Jukić, T. i Elez, M. (2013). Osposobljenost studenata nastavničkih studija za rad s djecom s govornim teškoćama u redovitoj nastavi. Pedagogijska istrą̌ivanja, 10, 1, 135-148.

12) Lacković-Grgin, K. (1994). Samopoimanje mladih. Jastrebarsko: Slap.

13) Lebedina-Manzoni, M., Novak, T. i Jeđud, I. (2006). Doživljaji sebe u obitelji. Kriminologija $i$ socijalna integracija, 2, 25-36.

14) Moreno Manso, J. M., \& Mateos Garcia, M. R. (2005). Estudio sobre la interrelación entre la dislalia y personalidad de niňo (A Study of the Interrelationship Between Dyslalia and Child Personality). Electronic Journal of Research in Educational Psychology, 3, 3, 133-150. doi: dx.doi.org/10.25115/ejrep.v3i7.1169

15) Rivera Tinoco, J. A. (2012). Las dislalias y su incidencia en la Autoestima de los niňos de segundo y tercer año de educación basica (The Dyslalias and its Impact on Self-Esteem of Children in Second and Third Years of Basic Education) (Diplomski rad). Loja: Universidad nacional de Loja.

16) Šego, J. (2009). Utjecaj okoline na govornokomunikacijsku kompetenciju djece; jezične igre kao poticaj dječjemu govornom razvoju. Govor, 26, 2, 119-149.

17) Śimić, M. (2015). Učestalost $i$ vrste dislalija u djece pred polazak u školu (diplomski rad). Zagreb: Filozofski fakultet.

18) Šola, P. (2017). Uloga kvalitete odnosa s vršnjacima u razvoju samopoštovanja $i$ socijalne kompetencije (završni rad). Osijek: Filozofski fakultet.

19) Vasta, R., Haith M. M. i Miller, S. A. (1998). Dječja psibologija. Jastrebarsko: Slap. 